\title{
Telling a Story Via Tumblr Analytics: Europe's Young Muslim Female Attraction to ISIS
}

\author{
Galit M. Ben-Israel (Fixler)* \\ Beit-Berl Academic College, Israel \\ ${ }^{\star}$ Corresponding Author: Galit M. Ben-Israel, Beit-Berl Academic College, Kfar Saba, Israel. \\ E-mail: galitbif@gmail.com
}

(Submitted 6 October 2017; revised 12 January 2018; accepted 3 March 2018; first published online 17 September 2018)

\begin{abstract}
This article is part of an effort to understand the enthusiasm, attraction and admiration of the organization "Islamic State in Iraq and Syria" (ISIS) among the young Muslim female in Western Europe. The article specifically focuses on microblogging (Tumblr and Twitter) contents of young Muslim girls from Western Europe. The study offers a review of ISISadoring Tumblr fangirls in the West through the prism of cultural interpretation. The young girls, whether themselves manipulated or manipulating others, become part of a worldwide viral system produced in perfect unison and generating propaganda enticing more and more young Muslim girls in the West to become viral ISIS recruits. After maintaining for a while Tumblr and Twitter accounts, some of them even undergo the "giant leap" and migrate to the "Islamic State" in Syria, continuing there to reinforce their blogging and twittering efforts, reporting on their daily lives and attempting to tempt or to trap more young girls to join the new "Islamic State".
\end{abstract}

Keywords "Islamic State"; fangirls; social media content; Twitter; Tumblr

\section{INTRODUCTION}

Attraction of Muslim girls in Western Europe towards the jihadist rhetoric of the "Islamic State in Iraq and Syria" (ISIS) requires a preview of what was before. Neumann and Rogers (2007) suggest that the radicalization became possible and comes into expression in religious discourse because experiences of exclusion and discrimination in Western society constitute one of the most powerful triggers in the European context. European Muslims, especially of the second and the third generations, often feel that - despite governments' inclusive rhetoric - Western societies have not offered them the full respect and equality that they believe they deserve. Violent extremists have long realized that this sense of alienation and social frustration can be capitalized on in order to attract recruits (Neumann and Rogers 2007). Throughout Europe, officials are again sounding alarms about radicalization among Muslim youth. As has long been the case, many of them are radicalizing through the Internet, thanks to various extremist websites and YouTube videos, several featuring 
US and European preachers. Others are being led by imams at their local mosques and, in the UK, by schools (Esman 2014). Officials say the threat has changed over the recent 2 years, since the days of Al-Qaida. Osama bin Laden's group had the flexibility common to Islamist terror networks, often developing plots based on the initiative, expertise and availability of recruits who reached its secret compounds in Afghanistan and Pakistan, or were recruited in London mosques. Over the last 2 years ISIS directly recruited young Muslim European men and women through social media like blogs, Twitter and cross-platform-encrypted instant messaging applications (apps) for smartphones and then lured them directly to Syria through Turkey (Rotella 2016).

Specifically on the subject of this paper, the attraction of Muslim girls in Western Europe to the jihadist rhetoric of ISIS requires an explanation of why this phenomenon is happening now. The answer is of course complex and I would suggest in brief three effects triggering the present phenomenon: first, the advent of the Web 2.0 revolution including social networks, smartphones, apps, etc.; second, ISIS separating itself from Al-Qaeda and turning out to be the most viral "organization" on the net; third, the second and the third generations (Muslim orientation) in Western Europe and the USA are perfectly suited to the messages, rhythm and technology of ISIS 2.0. This study covers young West European females who come from traditional AsianMuslim-orientated families on the one hand, and who are fully aware of all the digital technological innovations as well as all the Western teenager trends on the other hand. They are therefore the best candidates to cooperate and to make others cooperate with ISIS and broadcast its propaganda online by means of Tumblr, Twitter, Instagram and Ask.fm.

\section{THE WEB 2.0 REVOLUTION}

The world has changed completely: first, at the end of the 20th century, the Internet (Web 1.0) entered into people's everyday lives; second, at the beginning of the 21st century, Google and the social media revolution (Web 2.0) together with the invention of the smartphone, iPhone, Android, tablets and apps (application software) became life itself (Cormode and Krishnamurthy 2008).

Nowadays, $50 \%$ of the people in the world have Internet access and nearly $25 \%$ of the people in the world use social media (Ahmad 2013). The Web 2.0 era (Anderson 2007 ) is one of users who fill the empty platforms with information and know-how by means of Google searches and by uploading statuses, posts, photographs, video clips, films and music, tweeting tweets as well as location updates on social media. Since 2004, "Web 2.0" suggests a new version of the World Wide Web. It allows users to interact and collaborate with each other in a social media dialogue as creators of user-generated content in a virtual community. Examples of Web 2.0 include social networking sites (mainly Facebook, Twitter, Instagram, Pinterest, Reddit), blogs, wikis, video-sharing sites (YouTube), hosted services, web applications, WhatsApp, Telegram, etc.

\section{ISIS SPREAD TERRITORIALLY AND GOES VIRAL}

The "Islamic State" (also known as ISIS, IS and Daesh) appeals to a wide audience of Muslim communities around the world through the mechanisms of distribution of content and media campaigns and social networks. At the same time, ISIS is a 
recruitment magnet in Middle East territory under its control. During the second half of 2014, the "Islamic State" dominated a huge territory in northeastern Syria and the western and northern part of Iraq. In addition, it has accepted the oath of various jihadi Salafist organizations in Africa, Asia and the Middle East (Jenkins 2015). ISIS has established support cells throughout the Muslim world, including Muslim communities in the West (Europe, USA, Canada and Australia). As of July 2016, US officials say the group had lost nearly half of the territory that it once controlled in Iraq, and a quarter of the territory in Syria on the one hand but enlarged its terroristic power all over the world on the other hand. Almost every day "lone wolf" attacks, directed or inspired by ISIS, occur (Bazzi 2016); just some of the locations of these "lone wolf" attacks were: Tel-Aviv, Baghdad, Orlando, Istanbul, Paris, Brussels, Medina, Dhaka, Nice and Munich. ISIS "developed traditional means of communication that served their purpose in their direct interaction with the local population, but the most effective tool was the Internet, especially social networks and YouTube, which provided ISIS with cheap outlets and the ability to reach a wide audience scattered all over the globe" (Al-Qarawee 2015:165).

ISIS has built a narrative with heroes and plots and won the attention of Western media and Western public opinion. ISIS has also managed to divert Western media and public attention from the current reality in its territories (the suppression of the population, the suppressed women, the executions, the financial problems, the widespread starvation, the losses in battles, etc.). In fact, ISIS has succeeded in creating a social consciousness by infiltrating and manipulating the social networks most effectively. ISIS uses social media to unite the "ummah", namely to build an Islamic civilization multilingual ummah that includes "good Muslims" from all races. ISIS is able to fill any vacuum in its path (usually with no real resistance) and has succeeded in creating for itself the romantic image of a magician. ISIS's oppression, power and incredible violence signal a renewed pride and sense of belonging.

"More than a quarter of the Western militants in New America's dataset were reported either to have been active in online jihadist circles or to have radicalized via interaction online. This is likely an undercount for many of the individuals in the dataset the details of their radicalization path have not been reported" (Bergen et al. 2015:8). ISIS's fans have presence in almost every social network, including Twitter, Facebook, Tumblr, Instagram, YouTube, Telegram and docs-sharing sites. A recent study found that Twitter is ISIS's most effective tool for reaching new recruits. By using popular hashtags (\#) linked to cultural phenomena or popular events, ISIS can share its propaganda with millions of users across the world. "And until recently, Twitter itself did very little to censor accounts linked to the terrorist group. If an ISIS message piques the interest of a disaffected teenager in Wisconsin, they're just a tweet away from fraternizing with jihadism" (Brown 2016).

\section{THE SECOND AND THIRD GENERATIONS (MUSLIM-EUROPEAN DIASPORA) - ISIS FANS}

The second and third generations (belonging to the Muslim-European diaspora) are young people who control Western digital language and Western society codes. A few years ago the second generation was out there in the diaspora forums and chat rooms seeking comfort, spiritual guidance and identity (Shorer-Zeltser and Ben-Israel 2007). Nowadays the second and third generations are on Web 2.0 
(mainly Tumblr, Twitter, Reddit, YouTube, Instagram and Telegram). Some of them are ISIS supporters, jihadi fan bloggers who call for "lone wolf" attacks and fangirls crushing on hunky fighters who cuddle kittens (Cuen 2015).

Social media posts reveal that young ISIS devotees have great admiration for the "Islamic State" and its jihadists, not unlike the sentiments displayed by fans of sports clubs and stars in the sports or entertainment world. As for young women devotees of ISIS, Melanie Smith calls them "ISIS-fangirls" (Vinograd 2014). "The MerriamWebster online dictionary defines 'fan' as an enthusiastic devotee (as of a sport or a performing art) usually as a spectator and an ardent admirer or enthusiast (as of a celebrity or a pursuit). When adding, according to the same dictionary source, that the term fan is probably a short form for 'fanatic', it makes sense to consider these young Muslim women in the West as part of a virtual fandom community similar to fanatic fan groups devoted to sports teams, pop bands, or Hollywood celebrities" (Nacos 2015). Based on their analysis of Twitter data concerning the 2012 edition of the Eurovision Song Contest, Tim Highfield characterized "Twitter as an important new medium facilitating the connection and communion of fans. We can assume that the same is true for other social media platforms" (Highfield, Harrington, and Bruns 2013:315). Indeed, "ISIS relies on a multifaceted online strategy to recruit and advise potential foreign fighters and supporters. This includes both active efforts by individuals with social media accounts to recruit and organize other individuals as well as a more broad-based dissemination of propaganda. In the fall of 2014, J. M. Berger and Jonathon Morgan estimated that there were 'no fewer than 46,000 Twitter accounts supporting ISIS' overtly and a maximum of 90,000 ISIS supporter accounts on Twitter" (Berger and Morgan 2015).

Using this massive social media serves as a mechanism for distributing the products of the ISIS organization's various media, including high-quality movies, images, English and French magazines, books and e-books in multiple languages and Islamic chants (Koerner 2016). “This allows the organization's supporters around the world to learn about ISIS' actions and successes, stay up to date on recent developments and help passing ISIS' message. ISIS' fan in social media has a significance role in distributing ISIS' message" (Cuen 2015). Also, concerning the subject of our research, the microblogging of ISIS fangirls has had a significant role in distributing the ISIS message. This phenomenon or trend was already identified by the British authorities, the media, academic researchers and public opinion in late 2013.

\section{THE METHODOLOGY}

For this study we analysed mainly Tumblr (blogs) and Twitter accounts that belong to ISIS fangirls mainly in Western Europe. Another method used in this research is the interpretive approach applied in the analysis of culture and society, influenced by phenomenology in addition to the philosophical interpretive tradition. Historians have come to use this methodological tool because it incorporates a more realistic perception of society (Apel 1984). The interpretive approach assumes that people create and associate their own subjective and inter-subjective meanings as they interact with the world around them (Orlikowski and Baroudi 1991), and express a common interpretation of symbols (Habermas 1990). 


\section{WHY ARE FEMALES ESSENTIAL TO THE "ISLAMIC STATE"?}

ISIS has identified women as fundamental to its objectives and operations for this very reason, and subsequently tailored its recruitment campaigns to specifically target females (Zingg 2015). ISIS adopted ideological radicalization and ideas regarding the role of the female on attraction and recruitment of men. Women, who in themselves, however, have a vital role to play in the ISIS grand scheme, have been lured in by slogans praising the woman's restoration to her traditional given role in Islam, namely that women should invest their time in being mothers, housewives and partakers in the bloody war led by ISIS. This precept differentiates ISIS from AlQaeda who always kept female participation in terrorism undercover and unpublicized. However, both organizations are horribly detestable in their ideological radicalization and terror crimes. ISIS has revealed the true nature of the extremist belief system it applies where women are concerned. The terrorist group has taken advantage of female figures for purposes of recruitment, of promoting terrorist ideology and in the long run for employing them as terrorist practitioners. Terrorist females have become an ISIS hallmark throughout the world and a main anchor for extremism (Al-Haida 2016). Haras Rafiq, an expert on extremism with the Londonbased Quilliam Foundation says, "of course when building a state, what better way to build a state for longevity than to have families ... To have families you need women to come over as well" (Vinograd 2014). Zingg (2015) suggests that "the Islamic State's focus on women is central to their objective of longevity: in order to create a genuine state, they need women to bear children and raise them under their radicalized belief system" (Zingg 2015:14).

A study conducted by the International Centre for Counter-Terrorism (ICCT), based on analysis of 15 issues of Dabiq, suggests that "IS tends to portray women in five ways: contributor, mother/sister/wife, defender/fighter, corruptor and victim. Each of these female archetypes fits into one of two categories: part of the revered ingroup identity and its divinely ordained solutions or part of a despised out-group identity and a cause of crises. Dabiq's narratives thus compel their female readers to aspire towards the archetypes within the former but be wary of and reject those in the latter" (Ingram 2016).

Mia Bloom suggests that "ISIS has targeted women in ways similar to [the ways] al-Qaida did before it, in that women are a mainstay of their propaganda and recruitment ... However, unlike al-Qaida, ISIS has commoditised women and uses the lure and promise of marriage to attract thousands of foreign fighters from the [Middle East and North Africa region] ... So, not only are the women ranked and then awarded to the men based on all kinds of criteria - including eye and skin colour - but, after the husbands are killed, they are recirculated in the system ... and gifted again" (Fenton 2016).

Tatiana Dronzina claims that women are essential to the "Islamic State" for two reasons: first, in an organization which includes only men, and women are a limited resource, sooner or later there is the issue of compensation of the deficit; second, ISIS is the only terrorist group that claims to an ummah. An ummah cannot exist without a family, without a community of people linked by ties of love, mutual support and common goals and aspirations. That's why a call was sent to Muslim women around the world to join the "Jihad al-Nikah" or love jihad. The term appeared in 2013, when the Edict of Wahhabi Sunni urged women to go to Syria and Iraq to become 
"comfort women" in order to maintain the morale of the fighters (Ivanova 2016). Sasha Havlicek, founder of the London-based Institute of Strategic Dialogue (ISD), suggests "that recruiting Western women is an important part of the Islamic state's propaganda strategy. It helps build the idea that the group is about more than violence - it's constructing an 'Islamic state"' (Kaplan 2014).

Western women are recruited to ISIS "based on the idea of following their duty as Muslims by surrendering themselves to the male fighters and maintaining men's and women's morale and commitment to the cause. Correspondingly, men are recruited based on the idea that women will be available to them sexually and for general support, while women are recruited based on their sense of duty to Islam and the potential of becoming a martyr wife" (Katz 2015:31).

A team of researchers at the University of Miami who examined the role of women in extreme networks or organizations, such as terrorist groups, dispelled the common assumption that women are lured into these dangerous environments solely to offer support while men are recruited and tend to be the key players. Instead, the researchers found, women are better connected within the network, essentially becoming the glue holding the system together, fueling its vitality and survival. The study proposes that women in the pro-ISIS groups have a high BC ("betweenness centrality" = a glue that holds the network together) and hence play a central role by passing on vital information, from recruitment messages to files, or video and audio ISIS propaganda (Manrique et al. 2016). The research was performed among female Russian speakers in the Russian VK network that parallels Facebook and therefore its findings must be treated with some reserve in the context of this study.

\section{WHY IS EUROPE'S YOUNG FEMALE MUSLIM COMMUNITY JOINING ISIS?}

A report by the non-partisan public policy institute, New America, has found that women are joining ISIS in "unprecedented numbers". One in seven Western militants tracked by New America is a woman. "While Western women are not going to fight in the war in Syria, they are playing supporting roles, often marrying frontline fighters and sometimes working as a kind of police force that enforces ISIS's draconian laws" (Bergen et al. 2015:6). According to the ISD, as many as 550 women have fled the West to join ISIS (Petrou 2015). As of March 2015, approximately 10\% of the Islamic State's Western recruits are women, who have left Europe, North America and Australia to join the group in ISIS-controlled cities like Raqqa and Mosul (Huckerby 2015). In France, the number of female recruits is startlingly higher: roughly 63 of the 350 French nationals believed to have joined the group are women, or just under 20\% (Zingg 2015).

Clusters of women from mainland Europe have traveled to Syria after attending Islamic classes in mosques - from France a group of Chechen women emigrated together - but British women have tended to go alone. "The profile is very mixed across Europe. In the UK, many come from second-generation families from south Asia, because that's the biggest Muslim community here. They are school leavers and a couple of university students" (Khaleeli 2014). Furthermore, these young British girls, after immigrating to Syria, began to actively recruit friends and social media followers to join them in the struggle to create a Caliphate and wage war. Girls like Aqsa Mahmood, who had changed her name to Umm-Layth, had "begun professing the joys of hearing about beheadings of 'Kuffars', non-Muslims, on her Twitter and 
Tumblr accounts and making a blog that provided practical instructions on how to get into Syria and the rewards awaiting when married to a 'soldier of God' and the glory of Islamic war waged by Islamic state ... She now apparently runs the alKhanssaa brigade, a female-only militia of jihadists, who find the women for frontline fighters either as sex slaves, if they are deemed inferior, or as wives" (Miranda 2015).

Brigitte Nacos claims that nobody knows for sure why young women, used to the stability and comfort of Western societies, leave their families and friends for lives in a far-away war zone to become brides of ISIS fighters. Some observers suggest that these young females are the victims of online propaganda and brainwashing, turning the seemingly "normal" women next door into religious zealots; others believe that young women, just like young men, are bored and seek adventure; still others see admiration and love for courageous Islamic warriors as driving motivators (Nacos 2015).

The London-based ISD study, “Till Martyrdom Do Us Part", looked at why women and girls were being recruited, the diversity of roles they take on, and how to combat the threat. "ISD tracked more than 100 Western women across online platforms like Twitter, Facebook, and Tumblr. Women can be pushed to join ISIS because they feel isolated, persecuted, or they feel an anger or sadness about perceived lack of international action against injustice ... they might also be drawn or pulled by idealistic goals about building a caliphate; want to belong to a sisterhood; or glamorize what their experience with ISIS might be like" (Fenton 2016). The study also found that suffering from depression, and being financially comfortable, welleducated and socially isolated, were common factors among those sympathetic to acts of terrorism and those in contact with radical, unorthodox beliefs. "Those whose families had lived in the UK for generations were more vulnerable than migrants" (Bhui, Everitt, and Jones 2014).

Tarras-Wahlberg's thesis concerning official ISIS propaganda targeting women concludes that women are promised the possibility of fulfill their religious duty, become important state builders, experience deep and meaningful belonging and sisterhood, and to live an exciting adventure and find true romance; being increasingly influential is also promised. Official propaganda does not make explicit promises to women of exerting violence (Tarras-Wahlberg 2016).

\section{Historical Context}

To understand the women of ISIS and their motivations, it helps to place them in their historical context, among other female terrorists in the modern era. We see women in leftist and nationalist organizations across the globe by the 1960s and 1970s like: "The Red Brigades", "Red Army Fraction", "Liberation Tigers of Tamil", "Shining Path-Peru", "Popular Front of Liberation of Palestine", etc. (Raghavan and Balasubramaniyan 2014).

Between 1985 and 2010, female bombers committed over 257 suicide attacks representing about a quarter of the total on behalf of many different terrorist organizations. The percentage of women since 2002 in some countries exceeds as much as $50 \%$ of the operatives. The women have killed hundreds of men, women and children and their acts have maimed, blinded or crippled thousands more. Dozens more have tried and failed, and allegedly hundreds are being trained for the future 
(Bloom 2011). By the 1990s and certainly since the 2000s women have been increasingly involved with Islamist and jihadi terrorist organizations throughout the world, like "Al Qaeda", "Riyad-us Saliheen Brigade of Martyrsas", etc., as well as right-wing and left-wing terrorist groups, and environmental and animal rights groups, for example (Sutten 2009; Lindemann 2015). Between 1981 and 2007, of all suicide attacks in the Middle East, $26 \%$ were women, and woman jihadists were now becoming common place, at least according to ISIS propaganda (Miranda 2015).

"Female terrorists are not a new phenomenon. Women have previously played active roles in Terrorist groups ... Rarely; however, have women been part of a terrorist network's central body or key strategic focus. The responsibility most often expected of women has been" (Zingg 2015:14) "to sustain an insurgency by giving birth to many fighters and raising them in a revolutionary environment" (Petrou 2015).

\section{Like Men}

A study from the Queen Mary University of London from 2015 reveals that British Muslim women and girls are just as vulnerable to becoming radicalized as their male peers. The news comes amid reports of girls as young as 14 years old traveling to Syria from the West, to marry Islamist fighters, bear their children and join their communities (Saltman and Smith 2015). Kamaldeep Bhui claims that gender did not play a significant role in the risk of radicalization: "Women are no less likely in our analysis to have sympathies. If anything, they were more likely to show such sympathy, but not significantly so. There is an increasing epidemic of girls" (McVeigh 2014). Melani Smith says, "They are going for adventure, just like the young men" (Khaleeli 2014).

Jamie Dettmer suggests that some young Western women are attracted to ISIS by the same messages as Western men: ranging from religious obligation to adventure to solidarity with Syrians in the fight against the Assad regime (Dettmer 2014). The horrors of the Syrian conflict are cited as the motivating factor by many women who have travelled to Syria, says Smith. Khan also agrees that anger about foreign policy plays a part in young people being drawn to extremism. Intense identification with Muslim sufferings abroad, coupled with anger about British foreign policy, can be used to suggest the ummah is under attack, and needs defending. Baroness Warsi suggests that "the British lack of response over the crises in Gaza was a basis for radicalization that could have consequences for years to come" (Khaleeli 2014).

\section{Breaking Norms}

Young girls want to break the social norms of the patriarchal traditional Muslim system. They feel equal to the young boys beside them (Ben-Israel 2016). They include Aqsa Mahmood, team leader of Al-Hans, "al amriqui" from the USA and the two twin sisters from the UK, Kurdish female Kurdistan Workers' Party (PKK) fighters, a Western girl who works in Starbucks, etc. "A significant number of women and girls from Western countries have also answered ISIS call to jihad, as part of an active online recruiting campaign. As reported on incredulously in Western media, teen girls from countries such as Austria, England, the Netherlands, and the United States have sought to join the group; an estimated 100 women from Germany mostly between the ages of 16 and 27 - have traveled to Syria and Iraq to join ISIS, 
some with their husbands while others went on their own to marry or fight in the movement; others have been stopped by authorities en route" (Brooks 2015). Magnus Ranstorp claims that ISIS just recruits anyone, and there are many roles in the proclaimed caliphate (religious-based state) that women can play (Fenton 2016). Bhatia claims that "the rise in female jihad stems from the desire for self-empowerment, political recognition, and gender equality” (Bhatia 2015:13).

\section{Romance, Marriage, Mothers, Children}

Melanie Smith, a research associate with the International Centre for the Study of Radicalisation and Political Violence, has been tracking the movements of foreign fighters to Syria. They include 21 women who have traveled from Europe to the country. She said that most are undertaking "typical" female roles: making house and establishing community and support structures - not fighting. Most of the women fit into two groups: those who travel with their husbands to jihad, and those who travel to Syria or Iraq to get married. The latter is "certainly a trend". She assumes that this is a trend that will grow. "Many questions flood the male foreign fighters on social media about the possibility of marrying them or even being their third wife. They are generally answered in a positive way and asked to move to a more private platform" (Vinograd 2014).

Smith says the profile of ISIS recruits has changed. "The girls are getting younger," she says - typically aged 19 or 20 years. Nor do they seem to be particularly fanatical in their piety. The first recruits to Islamic State had practised an extreme interpretation of Islam all their lives. The women responding now, she says, "are going for adventure, just like the young men". Yet it is obvious from the comments posted online that many are also attracted to the idea of marrying a foreign fighter, seen as a heroic figure willing to sacrifice himself for a cause. The attention from girls and women has even led to some exasperated jihadists to ask their online followers to stop sending marriage proposals on social media, as it is not "halal" - or religiously permissible (Khaleeli 2014).

Tatiana Dronzina also suggests romance, partnership, marriage and the desire to gamble, alongside the message that is brought to them, about the multi amount of available men in the ISIS tribe (Ivanova 2016). Brooks also claims that ISIS has used a romanticized narrative of marriage to attract women as wives and future mothers for jihadi fighters. "Women give birth to the mujahideen [warriors] and they are the ones who raise them and teach them," notes one Western jihadi woman (Brooks 2015). "For some women, the appeal to join IS and marry a fighter is the start of what they believe is to be the creation of a new nation. To be a founding mother of a nation and have children to continue what they see as the struggle" (Miranda 2015).

\section{The Desire to Gamble, The Goal of Life, Sense of Belonging}

Mia Bloom claims that for each "type" of women ISIS is trying to attract, they adopt a different message. For example, they offer older women convert the chance "to create a new identity" and for the young women, the message is also tailored to basically prey "upon their innate altruism to do something important and 'good' with their lives." "Life is inaccurately portrayed as one filled with excitement where they will play an important part" (Fenton 2016). 
ISIS may appear to offer an escape from a nation where to be an equal citizen requires abandoning the dictates of one's religion. From this perspective, the ISIS denunciation of national identity in favor of a faith-based identity transcends borders in a crudely welcoming way. For example: on her blog, Umm-Layth (formerly Aqsa Mahmood) explains that in territory that ISIS controls, Muslim women are not mocked for wearing Islamic clothing and instead receive nothing but "respect and honor" (Zakaria 2015).

Sara Khan also offers arguments similar to those of Zakaria. Khan says that many Muslim women feel that the UK is increasingly hostile to Muslims. "With Muslim women more likely to be the victims of Islamophobic attacks than men, and facing barriers such as lower levels of employment and qualifications than the population as a whole, this can add to existing feelings of disenfranchisement" (Khaleeli 2014). Also "these young girls are the 9/11 generation - and they are constantly told that it is Muslims in this country who are the problem ... Media discussions of issues to do with Muslim women have not helped ... In the last year, the debates have all been about gender segregation, the niqab, hysteria about halal meat, the charity commission focusing on Islamic charities. That ... really is going to alienate them. And they will look to something that offers them belonging" (Khaleeli 2014).

Havlicek claims that ISIS sends foreign women a compelling message. "Given the choice of a fairly mundane life in a second-tier job in the West, and this rather heroic and romantic image of jihadi life being portrayed by Islamic State propaganda, which is very well crafted, in a paradoxical way this gives women a sense of agency and empowerment" (Kaplan 2014). Smith, Sara Khan, and Sayeeda Warsi suggest that joining extremist groups can be seen as cool as well, while the lack of a sense of belonging has led to a renewed interest and identification with the ummah, the worldwide community of Muslims (Khaleeli 2014). Kalsoom Bashir, co-director of a British Muslim education organization called Inspire, added that life among jihadists promises status and a sense of belonging - another compelling "pull" factor for young Muslims who increasingly feel left out of mainstream British society. "When they still feel as part of the other, and they have religious ideologies telling them that this is a way to have purpose and duty, that provides a breeding ground for the next step" (Kaplan 2014). Tatiana Dronzina speaks about "the painful process of finding their own individuality inherent in any young person, almost everyone is looking at this kind of emigration as a transition to a better life, where their values are put into practice, and their feminine essence will find complete satisfaction. They, like any other, need a goal in their life; they need a sense of belonging to a community that shares their values and beliefs" (Ivanova 2016).

Perešin (2015) claims that:

In the newly proclaimed 'Caliphate' some women see a chance to take part in the state-building process and to participate in the creation of a new society that would be built in contrast to the 'decadent and morally corrupt Western society, which has no respect for women'. With that in mind, women talk about joining the state, not a terrorist group, and expect to be given an important role in creating the new, ideologically-pure state, where they could live 'honourably' under a strict interpretation of Shariah law.

\section{Radicalism, Religion, Islamic-Utopia}

After carrying out a series of interviews with teenagers in the banlieues, the povertystricken suburbs of Paris which have become a breeding ground for extremism, the 
French journalist Anna Erelle concluded, “They knew very little about religion. They had hardly read a book and they learnt jihad before religion. They'd tell me, 'You think with your head, we think with our hearts.' They had a romantic view of radicalism. I wondered how that happened" (Driscoll 2015). Magnus Ranstorp claims that "many younger women are rebelling against patriarchal structures and they have a 'romanticized notion about what the caliphate is"' (Fenton 2016). Dabiq, the online magazine used by the "Islamic State" of Iraq and the Levant for propaganda and recruitment, suggests that the most prominent archetype of women is that of "contributor": "the woman who performs hijrah to the Caliphate as an essential expression of her female Muslim identity. By fulfilling this obligation, these 'contributors' not only actively solve their own individual crises and reverse the ills imposed on them by the West (a topic which is addressed in Dabiq 15's 'The Fitrah of Mankind and the Near Extinction of the Western Woman') but solve the Muslim community's collective crisis through building an 'Islamic-utopia'" (Ingram 2016).

Khan says that the older Muslim generation in the UK is more likely to rely on a culturally influenced interpretation of Islam, passed down through community norms and oral tradition, but younger women may rebel against this, using religion to challenge their parents' strictures on everything from arranged marriages to education. That's why some of the young girls choose ultra-conservative sources as their guide, upon mainstream interpretations. "There is a feeling that the more hardline your interpretation, the more authentic it is, and that's not the case at all it's just not true of Islamic law" (Khaleeli 2014). Another option is that ISIS appeals to some Muslim women, because they present Islamic utopia (illusory and false) (Zakaria 2015). Anne Speckhard (2016) also claims that:

As long as the idea of the longed-for Caliphate continues to carry its euphoric power, and ISIS continues to demonstrate some modicum of success in holding and governing territory, young girls who are angry or concerned over geopolitical events, who become convinced that militant jihad is their Islamic duty, and who feel off their track in the West, while simultaneously enticed via the Internet (often in person) by adventure, romance and the call to live (as they imagine) by Islamic ideals while they contribute to building a longed for utopia-that they will continue to be seduced into the movement, and we will continue to see females leaving the West to become Brides of ISIS.

\section{From No-One Position to Princess Position}

Anna Erelle declares that the teenager in the banlieues poor neighborhood: "feels like a nobody and all of a sudden here is this man of 38, nearly twice her age, who has had all these incredible adventures, who is kind to her and telling her he loves her and wanting to talk to her 1,000 times a day" (Driscoll 2015). "When you get here, you'll be treated like a princess ... This is why girls go there. It's the dream of a good life. They are persuaded that it's a paradise and that they don't have any future in Britain or France and they won't find good husbands and can never be good Muslims surrounded by infidels. Bilel told Melodie she could have a beautiful life, a big apartment and lots of children" (Driscoll 2015).

\section{Sisterhood and "Sisterhood"}

"By late 2013, British authorities started to note a new trend, the online chatter buried in the slang or otherwise inane emails and texts from the girls like Mahmood 
to friends back home. Whether it was in their hand or just in their name, the idealist women had begun to actively recruit friends and social media followers to join them in the struggle to create a Caliphate and wage war" (Miranda 2015). Bloom claims "ISIS propaganda also emphasizes sisterhood and the chance to live in a community of like-minded women. In addition to emphasizing that women will be important and significant, they say that they will not be lonely and [will] have a support network of other women. ISIS propaganda also emphasizes sisterhood and the chance to live in a community of like-minded women" (Fenton 2016). Erin Saltman at ISD says: "There is a strong sense that you are joining a family. ISIS really plays up the fact that you are among sisters. Part of it almost plays out a feminist narrative, which says that the West sexualizes women and in 'Islamic State' territory, you are treated with respect" (Petrou 2015).

Anna Erelle, the French journalist, tells in her book, In the Skin of a Jihadist, that she met a "maman", a woman that accompanies the lured teenagers from Western Europe into the "Islamic State" territory in Syria to marry the Mujahideen warriors (Erelle and Potter 2015). Some of the European women already in the ranks of the "Islamic State" are trying to lure their "sisters" to the marriage beds of the caliphate's holy warriors. This is ISIS showing, once again, that it is almost as shrewd with social media as it is ruthless on the battlefield. The tweets and blogs apparently are written by Western women married to jihadi warriors. They aim to persuade would-be "sisters" in Europe and the USA to travel to the Middle East to help this "Al-Qaeda spinoff" (ISIS) build its extremist vision of an Islamic society. Potential candidates are told they will not contribute to the revolution through martyrdom but through matrimony. This means child-bearing and not gun-toting (Dettmer 2014).

Issacharoff (2016) reports that there are 400 women, both Syrian and Western, who operate as ISIS's female extension. Their role is to supervise the young women in the territory of the "Islamic State". They are allowed to impose penalties on them like: fines, physical and mental violence and imprisonment. The head of the women is a British woman named Um Abdallah. The role of these women is to recruit young women for private matters for the main leaders of ISIS and the warriors. Sometimes they force the young women to marry the warriors and some of the young females commit suicide because of their pressure (Issacharoff 2016). Another example is Aqsa Mahmood from Scotland, who was 20 years old when she changed from funloving university student to ISIS fanatic and fangirl in a matter of months and then radicalized and moved to Syria, married a local man then professed a hatred for the West. She changed her name to Umm-Layth, and she "now apparently runs the alKhanssaa brigade, a female-only militia of jihadists, who find the women for frontline fighters either as sex slaves, if they are deemed inferior, or as wives" (Miranda 2015).

\section{Fans, Teenagers and Celebrity}

Magnus Ranstorp, Anna Erelle, Brigitte Nacos and Melanie Smith all agree upon the subject that young women recruited to ISIS is a similar phenomenon to attraction to and admiration of celebrity of young teenagers in the West - fangirls. The really young girls, 14 to 16 years old, are usually recruited in groups, and social media play a significant role. Often, impressionable teens are lured by the idea of marriage to 
ISIS fighters who are portrayed as attractive and fit. Ranstorp observed that "They are like the Justin Biebers of the Salafi (ultra-conservative evangelical) jihadi world" (Fenton 2016). Al-Amriki (ISIS fangirl who holds several Tumblr, Twitter and Instagram accounts) routinely circulates posts by the ISIS Tumblr network and has gone from criticizing the group to saying ISIS fighters are the celebrities she would most like to meet (Cuen 2015).

Erelle claims that the "caliphates" are young women who had grown up in a free society but were obsessed with jihadist fighters. "To them, jihadists are like Brad Pitt, only better because Brad Pitt is not religious" (Driscoll 2015). Erelle also characterized the young females as longing to be celebrity themselves and becoming celebrity when they immigrate from their virtual community on Twitter in their teenager's room to Syria, by their virtual community and by the press (Driscoll 2015). "After looking at ISIS's female recruitment sites I wonder to what extent Internet and social media networks are instrumental in turning some impressionable girls and young women into fans of the 'Islamic State' and its fighters, just as entertainment media turn some of their peers into passionate fans of pop music stars or movie celebrities," Nacos claims (Nacos 2015).

Melanie Smith claims that the women tend to be young and "extremely pious and have been ISIS 'fangirls' for the duration of the Syrian conflict, active on social media" (Vinograd 2014). She called these women "Islamic State" "fangirls", "as though they were groupies for a boy band rather than a movement of violent religious extremists" (Kaplan 2014). Most worrying, according to Smith, is "the volume of those followers which she numbers in the 'hundreds', with the jihadi brides' chatty street-talking style Tweets and Instagram images hitting their mark. I come across girls every day who say, 'I'm so desperate to go over there but it's just so hard for me" (Miranda 2015).

Smith also adds: "For the moment, however, it's clear that women are only cheerleaders of such murders. Female members may tweet about practicing shooting or post photos of their guns, but experts say there is no evidence they are allowed to fight. Instead, they are expected to marry, keep house and bring up a new generation and strengthen the narrative that this is not a terrorist group, but a state all Muslims must join” (Khaleeli 2014). "In many ways, 'jihadi brides' like Mahmood are not so different from any other online subculture, Bashir added. Feeling marginalized in the real world, they are sold on the kind of alternate reality only the Internet can offer" (Kaplan 2014).

\section{GENERAL FINDINGS: TUMBLR ANALYTICS}

On January 2015 Erin Saltman and Melanie Smith, from King's College International Centre for the Study of Radicalisation and Political Violence, have been tracking, through their social media accounts, British women who have joined ISIS. The researchers suggested that some of the most active ISIS Tumblr promoters are distant fangirls, who may not initially be ISIS fans but become increasingly radicalized as they blog about jihad's romantic, cat-friendly lifestyle, replete with images of hunky fighters (Saltman and Smith 2015). Analysis of Tumblr posts demonstrate the skill ISIS continues to master in reaching across various social media platforms with savvy users who propagandize and recruit for the group. The favorite tools used by ISIS 
fangirls to spread jihad are Tumblr and Twitter. Following Saltman and Smith, I analysed ISIS fangirls' Tumblr posts.

\section{Aesthetic and Visual}

ISIS fangirls' posts are aesthetic, perfectly designed with clean paint lines appealing to the eye, full of visual images, icons, photographs, GIFs, plus nature and water images, all creating the illusion of an ideal world.

\section{Post-Modern Eclectic 2.0}

The blogs have a precise mixing of animals, digital technology, Islamic holism, war and military stuff and teenage Western pop culture: lions, Arabian horses, cats and kittens (the most popular online animal), next to holy books, mosques, minarets, Islamic clerics cuddling cats and kittens in courtyards of mosques. In addition, the blogs have mujahideen dressed in uniforms and armed with rifles softly cuddle kittens, executions, knives, Muslim prisoners dressed in orange and yellow uniforms in Guantanamo, AR-15 (M-16) Kalashnikov, AKC-74 Kalashnikov, etc., side by side with images of hearts, strawberries, plenty of pink color, soft blankets with Disney cartoon pink cat images. All of these images appearing as icons, selfies, GIFs, memes, etc. belong to the world of Web 2.0. See, for example, the blogger who calls herself al-Amriki (the American), "a 19-year-old vegan, who posts pictures of Islamist militants, often with flowers and animals, romantic poetry about jihad and heart-shaped ISIS trinkets. According to her ask.fm page, she's had over a dozen Instagram accounts banned. She has also purchased several guns" (Cuen 2015). Al-Amriki portrayed herself as a cartoon, dressed in black from head to toe, fully veiled. She holds a Kalashnikov AK-47 and a garland placed on her head. After the Western ISIS fangirls immigrate to the "Islamic State", they also post a postmodern mixture in Tumblr of: selfies, cats, kittens and sunset photographs alongside quotes from the Koran in the name of Allah, written in Arabic and English, calling for violence and executions. They also have discussions through Twitter and Ask.fm about ways to support the militant movement. For example: Umm-Layth (former Aqsa Mahmood, from Glasgow) had an image of a gun with a rose stuck in the barrel and included calls exhorting Muslims to carry out terrorist attacks in the West.

In some tweets by Zahra Halane, you can find the whole essence and basis of ISIS propaganda. It is also the essence of ISIS Tumblr fangirls - a surrealistic mix of Islam, religion and "militarism" with kittens, pink and strawberry. For example, one of the twin sisters, Zahra Halane, tweets on the subject of her missing ginger kitten (major leitmotif in ISIS propaganda and ISIS fangirls' Tumblr posts). She said the "tomcat 'disappeared' after her husband 'threw [it] outside"' (Taylor and Narain 2014). The cat is called Abu Hureyra (religious Islamic motif) after an ancient settlement by the Syrian city of Raqqa (Moore, Hillman, and Legge 2000), the "Islamic State" stronghold where the girls are thought to be living. Zahra tweets: "Abu hureyra disappeared!!!! inshaa Allah [God willing] we will be reunited in jannah [paradise]'. She accompanied the message with symbols for a crying face and a heart, later adding: 'my husband threw outside (sic)"' (Taylor and Narain 2014). 


\section{Islam}

The blogs are exclusively about "brothers", mujahideen, imams, clerks, mosques, minarets, the Black Stone of Mecca, the holy city of Mecca, martyrs, Muslim prisoners dressed in orange in Guantanamo, proverbs about Allah, justice, hadiths, etc. There are no female images, only small children or imams kneeling in prayer in mosques, dressed in white traditional Middle-Eastern dress. In some of the Tumblr blogs you can find photograph homage and GIF homage to Muhammad Ali and Malcolm X. After the immigration to Syria you can find images of the blog writers all covered in a black dress from head to toe.

\section{Symbols: Black Flag, Upward Directing Finger, Martyrdom}

ISIS is using a uniform design language for raising identification with the role of the "Islamic State", for the Muslims who live in ISIS territory and for the ones who live in the "Lands of unbelief". I also found ISIS uniform design language with its symbols on Tumblr and Twitter accounts of ISIS fangirls.

One important symbol of this new language is the black flag that appears in almost every photograph distributed by ISIS. Those loyal to ISIS are embedding the black flag in their social media accounts as a symbol of their affiliation to the "Islamic State". Another important symbol is the upward directing finger, a seemingly meaningful gesture indicating the principle of Tawhid (Arabic: توحيد tawhīd, the oneness of God), the indivisible oneness concept of monotheism in Islam. Tawhid is the religion's most fundamental concept and holds that God (Allah) is One (Al-'Ahad) and Single (Al-Wāhid). Osama bin Laden also used it but only with the ISIS design language has this gesture become particularly widespread and it actually expresses solidarity with its specific radical example rather than merely a general sympathy with the principle of Tawhid.

Another common symbol is Istishhad (Arabic: استشهاد), the Arabic word for "martyrdom", "death of a martyr", or "heroic death". ISIS presents the bodies of ISIS warrior casualties with a small smile on their faces, clean and with no bold stains on their faces, delivering the message that they had fulfilled their wish to be martyred. Additional underscoring of the message stems from the juxtaposition of bodies of enemy victims of ISIS for comparison with those of the martyrs. In such cases the bodies of the "enemy" victims are exposed desecrated to the fullest extent by ISIS warriors. Like other jihadist women, Umm-Layth, for example, posts in her blog in a manner of morbid obsession with martyrdom - "Allahu Akbar, there's no way to describe the feeling of sitting with the Akhawat [sisters] waiting on news of whose Husband has attained Shahadah [martyrdom]" (Dettmer 2014).

\section{"Softer Symbols": Cats, Kittens, Lions and Horses}

Other iconic symbols in the ISIS arsenal which frequently appear on ISIS fangirls' Tumblr posts contain softer symbols, such as animals. For example: green birds embody the hadith of certain souls who sacrificed their lives in martyrdom; lions are also a common symbol of the courage of ISIS warriors and lion cubs serve as a symbol of the future generation of the "Islamic State". The blogger behind "Musings of a Lioness" wrote: "The Islamic State said that we the media correspondents are Mujahideen too. So whatever happens remember Allah is with us and we have Allah so we have everything" (Cuen 2015). Bilel, an ISIS warrior who lured young Muslim females in France and was described in the book by Erelle and Potter, In the Skin of a Jihadist, wrote to one of the 
lured girls: "You are a big girl; Dozens of Europeans are making that journey every week in the hope of joining our ranks. Allez, ma lionne!" (Driscoll 2015). Another animal frequently used in fangirls' Tumblr blogs is a horse. The Arabian horse is a symbol of power, grace and sensitivity. Arabian horses are the topic of many myths and legends concerning the prophet Muhammad (Schofler 2006).

Other animal symbols are cats and kittens. The positive attitude of ISIS towards cats and kittens is based on the tradition concerning Abu Hurairah, who was one of the escorts of the young Prophet Muhammad. Abu Hurairah was known for his affection for cats. At the same time cat and kitten images are frequently used on ISIS social media accounts to show the human face, so to speak, of the "Islamic State". Children, imams in mosques and brutal ISIS mujahideen are photographed in thousands of saccharine poses with kittens in order to show that the Islamic State is cruel towards its enemies but compassionate towards creatures innocent of the crime of denial of Islam.

ISIS fighters cradling kittens and images of honeybees are an apparent attempt to soften the image and attract new recruits, especially young females. Shiraz Maher, Deputy Director of the International Centre for the Study of Radicalisation and Political Violence at King's College, London, claims that the use of "softer imagery" is common in ISIS propaganda aimed at Muslims (Dearden 2016). Thus, the softer imagery like kittens in ISIS fangirls' Tumblr accounts acts as a recurring tool used by the "sisters", side by side with the "hard images" to lure young Muslim-European females to cross the lines, to also become ISIS fangirls and to immigrate to the "Islamic State".

\section{Recruiting and Luring by "Sisterhood"}

Girls like Aqsa Mahmood, who had changed her name to Umm-Layth, had begun professing the joys of hearing about beheadings of "Kuffars", non-Muslims, on her Twitter and Tumblr accounts and making a blog that provided practical instructions on how to get into the "Islamic State"/Syria and the rewards awaiting when married to a "soldier of God" and the glory of Islamic war waged by "Islamic State". She now runs the al-Khanssa brigade, a female-only militia of jihadists, who find the women for frontline fighters either as sex slaves - if they were deemed inferior - or as wives (Winter 2015). Umm-Layth has more than 2,000 Twitter followers. She tweets: "I will never be able to do justice with words as to how this place makes me feel." She cherishes, she says, the friendships she enjoys with "her fellow sisters and brothers in the Islamic State" (Dettmer 2014).

In one of her tweets, Mahmood said while she felt a sense of community, of belonging, there were also mundane days under strict Sharia laws and their female war was more about supporting the men than taking up arms themselves. But it was from this standpoint that she also encourages others to bring the "battlefield" to Britain, her own boredom apparently prompting her to encourage others to make her own attack, and post it online no doubt (Miranda 2015). Mahmood tweeted: "Our role is even more important as women in Islam, since if we don't have sisters with the correct Aqeedah [conviction] and understanding who are willing to sacrifice all their desires and give up their families and lives in the West in order to make Hijrah [migration] and please Allah, then who will raise the next generation of Lions?" (Zakaria 2015). She also has advice for other British women hoping to become "jihadi brides": "Try and bring painkillers and Diahorea [sic] tablets... lol you will need it for the first month or 
so," she posted in April. Later, she wrote, "I will be straight up and blunt with you all, there is absolutely nothing for sisters to participate in Qitaal [fighting]" (Kaplan 2014).

Other recruiters are the "terror twins" Salma and Zahra Halane (16 years old) from Manchester who followed their brother into IS in Syria in June 2014. The sisters appeared to be typical teenagers, pouting for selfies and shopping (Reilly 2014).

The Halane twins form a particularly vocal sub-cluster of the British female migrant contingent, indicated by their constant resilience in overcoming online censorship mechanisms by alternating usernames, changing Twitter handles and using 'shout-out' tactics to regain their follower networks quickly and efficiently. This has allowed for their voices, like many others, to contribute persistently to the propaganda narratives perpetuated by female migrants to IS territory, bolstered by the knowledge that their accounts have established influence. Zahra and Salma have utilized various platforms to achieve such influence, predominantly Twitter and Instagram (Saltman and Smith 2015:20-1).

More specifically, Zahra Halane's online identity "demonstrates a higher level of political engagement and a much more direct approach to recruitment strategy" of young Muslim European girls, via her Twitter account (Saltman and Smith 2015:25).

In February 2015, Zahra Halane published photographs to Twitter purporting to show female migrants being trained in self-defence - wearing Nike Air trainers and shooting rifles at targets. Zahra describes this as a "fun day training ... with humble sisters" (Saltman and Smith 2015:26). Again, the whole ISIS propaganda in one tweet: trained female migrants, Nike Air trainers (a Western brand being used and mixed with jihad), targets, shooting rifles, fun and the cherry on the whipped cream - using the term "sisters" "as a group highlights the importance of 'sisterhood' in luring prospective migrants towards ISIS. It is clear from their social media presences that both twins have established strong friendships with other migrants, forming communities of ISIS wives and widows, particularly in Raqqah ... this sisterhood concept is leveraged as a recruitment tool, communicating the notion that while a migrant may lose their family as a result of their migration, they will simultaneously gain such a support structure in Syria" (Saltman and Smith 2015:26).

\section{The Daily Life in the "Islamic State" as Portrayed in ISIS Fangirls' Tumblr and Twitter Accounts}

British Muslim convert Grace "Khadijah" Dare appeared in a documentary 2 years ago with her ISIS fighter husband Abu Bakr and her son Isa in which she boasted about her new extremist life. In the documentary, fully-veiled Dare and her neighbor head to the shops in Aleppo with their children to buy "hummus, nappies and a bucket" while carrying Kalashnikov rifles over their shoulders in case of emergencies. Dare also has a photograph of herself in her Tumblr blog, fully veiled, in black and with a AKC-74 rifle. She posted a slogan: "If I thought Islam was an oppressive religion, I would have left Islam” (Myers 2016).

Salma Halane's attitude through her online persona is particularly well illustrated by her Ask.fm account, in which she responds to questions posed by anonymous senders. In her use of this platform, she responds concerning her relationship with her twin sister, her daily responsibilities in the "Islamic State" and her experience of being married to a jihadist warrior (Saltman and Smith 2015:25). 
Zahra Halane posted a picture - believed to be of herself - in a full veil holding an AK47, kneeling in front of the IS flag, a dagger and a grenade. Previous tweets from the account included messages such as "I support the executions of Syrian soldiers. It's self defence and pictures of machine guns alongside the Koran" (Taylor and Narain 2014). Again, in one ingenious tweet, we have the whole picture: ISIS flag, the holy Koran, machine guns, executions of Syrian soldiers, a kitten, a jihadist warrior husband, a married woman, Abu Hureyra and Abu Hurairah (hint embedded in the kitten story). One of the bloggers, going by the screen name "Bird of Jannah" promotes this lifestyle through one of her blog posts quoted here: "Women are not equal to men. It can never be. Men are the leaders \& women are special that Allah has given them entire chapter in the Qur'an" (Dettmer 2014).

One of the most popular ISIS bloggers is Salma-alAnsariya. Her blog urges Tumblr users in the West to plan their own terrorist attacks by saying: "You are living in a place where you can cause great harm to the enemy, the means of harming them are many, so seek assistance from Allah, and do not be weak and you will find a way" (Cuen 2015). Her Tumblr name is Umm Unknown. She posts a few pictures of what they eat "during our days off front lines: Pasta with tomatoe sauce and chicken. Cooked by Abu Sa'd Sudani. But hey, I cut the tomatoes, and that's the main ingredient for the TOMATOE sauce/paste right? So I guess I also deserve some praise for this dish, lol ... Pasta with chicken and sauce and cheese and everything else which makes your taste buds tingle. Made by Abu Sa'd Sudani ... A few snacks" (“Umm Unknown” Tumblr).

\section{SUMMARY AND CONCLUSIONS}

In this article I tried to understand the phenomenon of the ISIS fangirls' Tumblr accounts. First, I came to a conclusion regarding the reasons among the young Muslim female in the West for the enthusiasm, attraction and admiration of the organization ISIS; second, I specifically focused on microblogging (Tumblr and Twitter) contents of Muslim girls mainly from Western Europe.

As for the reasons, the main one in my opinion is because the leaders of the "Islamic State of Iraq and Syria" have identified women as being of fundamental importance to the objectives and operations of ISIS and have subsequently tailored their recruitment campaigns to specifically target females. The other primary reason is the designated role of Western women under ISIS-controlled territory - wife of the jihadist husband to whom they are betrothed and prospective mother to the next generation of jihadists. Of course, being wife and mother to a distant jihadist in a distant utopian "state" includes, in the eyes of the female teenagers, a romantic notion overcoming boredom as well as a desire for adventure and breaking of norms by means of self-empowerment, "gender equality", the transition "from a nobody to a princess" position and becoming increasingly influential. We can also add some more reasons such as: political recognition, victims of online propaganda and brainwashing, sense of belonging, building a caliphate, religion, radicalization, the desire to gamble, isolation, the goal of life, sisterhood, an anger or sadness about perceived lack of international action against injustice, anger about British foreign policy, fanship, teenagerism and celebrity. 


\section{What Can We Learn from the Tumblr and Twitter Accounts of the Young Girls Who} Immigrated to ISIS?

The blogs have a precise postmodern mixing of animals, digital technology Web 2.0, brands, Islamic holism, jihad, mujahideen executions, knives, rifles, and teenage Western pop culture (images of hearts, strawberries, usage of pink color, soft blankets with Disney cartoon pink cat images). Lions, Arabian horses, cats and kittens (the most popular animal online), next to holy books, mosques, minarets, Islamic clerics cuddling cats and kittens in courtyards of mosques also feature. All of these images that come as icons, selfies, GIFs, memes, etc. belong to the world of Web 2.0.

There is a huge difference between the posts written in Tumblr by the fangirls while living in the West, and the ones written by the same girls while living in the "Islamic State". The first type includes also Western symbols, especially brands, trends and teenagers stuff and no women images at all. The second type includes images of the owners of the blogs and their women friends, fully veiled, holding an AK47, or strolling in the streets of Aleppo and Raqqa, shopping and displaying their daily life. Sometimes the women post photographs and short videos with their mujahideen husbands and their children.

The first type was in some ways naïve or pretended to be naïve and recruited girls just to open more ISIS fangirls' Tumblr accounts. The second type glamorized the life under ISIS in Raqqa, Aleppo, etc. and provided practical instructions on how to get into the "Islamic State"/Syria, the awaited rewards when married to a "soldier of God" and the glory of Islamic war waged by the "Islamic State".

After careful observation mainly of Tumblr accounts but also of Twitter accounts, I can say that these girls and their Tumblr blogs are playing crucial roles in propaganda dissemination and online recruitment of more young women, both directly and indirectly, to become ISIS fangirls or to also immigrate to the "Islamic State".

Some questions arose in my mind while researching the ISIS fangirls' Tumblr accounts. Are the ISIS fangirls' Tumblr blogs copy guided from above? Or are they a copy viral trend? Are ISIS men and strategies behind these blogs? Who decided that the girls are part owners or sole owners of the accounts? Did they receive orders or instructions from ISIS headquarters while creating these blogs?

\section{What Can be Done?}

Women are the mainstays of the "Islamic State". We discussed in depth at the beginning of this article why females are essential to the "Islamic State". For ISIS, women are the support system and an integral part of the infrastructure necessary to set up a new society. The Islamic State's aggressive focus on female radicalization poses both a significant threat to international security and a critical opportunity for the West. In my opinion, we must take a twofold approach towards solving the problem: first, to physically and militarily liquidate the Islamic State and create the beginning of a new order in the Middle East (Syria and Iraq) - perhaps autonomous regions with autonomous, but not religious, regimes; and second, to satisfy an urgent need for a strong regulation, on the part of the West, of social media like Facebook, Instagram, Twitter, Tumblr, Telegram, etc. This would entail rapid deletion of blatant, inciting and instigating contents that are posted in the social media every day by these corporations.

However, we should remember that the idea of an Islamic state will not go away on its own. It raises its head anew somewhere else in the world each time. Prior to the 
Islamic State in Syria and Iraq an "Islamic State" headed by the Taliban was established and existed for 6 years (1995-2001) in Afghanistan until the American occupation/ liberation in October 2001. In 2014 splits from Al Qaeda (who were previously based in Afghanistan and Pakistan) established the Islamic State in parts of Syria and Iraq. It is a battle of ideas as much as it is a military conflict. Furthermore, we should remember that the strategists of the jihadist terror are clever and creative. Whenever the West thinks it has destroyed one of their phenomena they crop up in other ways, for example, nowadays the phenomena of "lone wolf" and the latest use by ISIS of child combatants.

\section{References}

Ahmad, Ifran. 2013. "Global Internet, Mobile and Social Media Engagement and Usage Stats and Facts." Social Media Today, December 11, 2013. Retrieved January 20, 2014 (https://www.socialmediatoday.com/content/ global-internet-mobile-and-social-media-engagement-and-usage-stats-and-facts-infographic).

Al-Haida, Abdollah. 2016. "Women Far More than 'Jihadi Brides' to ISIS." Asharq Ala Awsat, March 14, 2016. Retrieved April 2, 2016 (https://eng-archive.aawsat.com/abdollah-al-haida/news-middle-east/ women-far-more-than-jihadi-brides-to-isis).

Al-Qarawee, Harith H. 2015. "The Discourse of ISIS: Messages, Propaganda and Indoctrination." Pp. 145-66 in Twitter and Jihad: the Communication Strategy of ISIS, edited by Maggioni Monica and Paolo Magri. Milan: Italian Institute for International Political Studies (ISPI). Retrieved April 2, 2016 (http://www.ispionline.it/sites/default/files/pubblicazioni/twitter_and_jihad_en.pdf).

Anderson, Paul. 2007. "What is Web 2.0? Ideas, Technologies and Implications for Education." JISC Technology and Standards Watch. Retrieved January 20, 2014 (http://www.jisc.ac.uk/media/documents/ techwatch/tsw0701b.pdf).

Apel, Karl-Otto. 1984. Understanding and Explanation: A Transcendental-Pragmatic Perspective. Cambridge, MA: MIT Press.

Bazzi, Mohamad. 2016. "Terrorists Turn to Lone Wolf Attacks as Their Strength Diminishes." Vocative, July 15, 2016. Retrieved July 20, 2016 (http://www.vocativ.com/341305/terrorists-turn-to-lone-wolfattacks-as-recruits-and-territory-diminish/).

Ben-Israel, Galit. 2016. "Telling a Story via Tumbler Analytics: Europe's Young Female Muslim Attraction to ISIS." In NATO Advanced Research Workshop: Responses to Female Migration to ISIS, April 28, 2016, Venice, Italy.

Bergen, Peter, David Sterman, and Albert Ford. 2015. "ISIS in the West - The New Faces of Extremism." New America, November 2015. Retrieved April 20, 2016 (https://static.newamerica.org/attachments/ 11813-isis-in-the-west-2/ISP-Isis-In-The-West-v2.b4f2e9e3a7c94b9e9bd2a293bae2e759.pdf).

Berger, J. M. and Jonathon Morgan. 2015. The ISIS Twitter Census: Defining and Describing the Population of ISIS Supporters on Twitter. The Brookings Project on U.S. Relations with the Islamic World, Analysis Paper No. 20, March 2015. Retrieved April 20, 2016 (https://www.brookings.edu/wp-content/uploads/ 2016/06/isis_twitter_census_berger_morgan.pdf).

Bhatia, Kabir. 2015. "Understanding the Contradictions of the Islamist Jihad." Pp. 11-13 in Canada In the World: Youth Dialogue on Women, Peace, And Security, edited by Kabir Bhatia and Saman Rejali. Toronto: The Atlantic Council of Canada. Retrieved April 20, 2016 (http://natoassociation.ca/wpcontent/uploads/2015/05/Canada-in-the-World-Youth-Dialogue-on-Women-Peace-and-Security.pdf).

Bhui, Kamaldeep, Brian Everitt, and Edgar Jones. 2014. "Might Depression, Psychosocial Adversity, and Limited Social Assets Explain Vulnerability to and Resistance against Violent Radicalisation?" PLOS ONE 9(9):e105918.

Bloom, Mia. 2011. "Bombshells: Women and Terror." Philadelphia: PA: University of Pennsylvania Press. Brooks, Julia. 2015. "Understanding the Recruitment of Women and Girls to the Islamic State." ATHA, March 10, 2015. Retrieved April 2, 2016 (http://www.atha.se/blog/understanding-recruitment-womenand-girls-islamic-state).

Brown, Jennings. 2016. "DARK NET: Trying to Kill ISIS with Cuteness." Vocativ. March 3, 2016. Retrieved April 19, 2018 (http://www.vocativ.com/news/291750/isischan-dark-net). 
Cormode, Graham and Balachander Krishnamurthy. 2008. "Key Differences Between Web 1.0 and Web 2.0." First Monday, volume 13, issue 6. Retrieved October 1, 2015 (http://firstmonday.org/ojs/index.php/ $\mathrm{fm} /$ article/view/2125/1972).

Cuen, Leigh. 2015. "ISIS Fans Take to Tumblr to Blog and Spread Jihad." Vocativ, November 27, 2015. Retrieved April 20, 2016 (http://www.vocativ.com/news/254318/isis-jihadi-fangirls-tumblr/).

Dearden, Lizzie. 2016. "Isis Using Kittens and Honey Bees in Bid to Soften Image in Dabiq Propaganda Magazine." Independent, August 2, 2016. Retrieved April 19, 2018 (https://www.independent.co.uk/ news/world/middle-east/isis-kittens-honey-bees-dabiq-propaganda-recruits-photo-soften-image-terrora7168586.html).

Dettmer, Jamie. 2014. “The ISIS Online Campaign Luring Western Girls to Jihad." The Daily Beast, June 8, 2014. Retrieved April 1, 2016 (https://www.thedailybeast.com/the-isis-online-campaign-luring-westerngirls-to-jihad).

Driscoll, Margarette. 2015. "My ISIS Boyfriend: A Reporter's Undercover Life with a Terrorist." New York Post, March 7, 2015. Retrieved April 2, 2016 (http://nypost.com/2015/03/07/my-isis-boyfriend-areporters-undercover-life-with-a-terrorist/).

Erelle, Anna and Erin Potter. 2015. In the Skin of a Jihadist: A Young Journalist Enters the ISIS Recruitment Network. New York: Harper Collins.

Esman, Abigail R. 2014. "Experts Warn More European Muslim Youth Are Radicalizing." IPT News, April 25, 2014. Retrieved December 24, 2014 (https://www.investigativeproject.org/4362/experts-warn-moreeuropean-muslim-youth-are).

Fenton, Jenifer. 2016. "Sisterhood \& Social Media: Why More Western Women Are Joining ISIS." Refinery 29, March 30, 2016. Retrieved April 20, 2016 (https://www.refinery29.com/2016/03/106896/femalefighter-women-join-isis).

Habermas, Jürgen. 1990. "The Hermeneutical Claim to Universality." Pp. 245-72 in The Hermeneutic Tradition: From Ast to Ricoeur, edited by Alan D. Schrift and Gayle L. Ormiston. Albany, NY: State University of New York.

Highfield, Tim, Stephen Harrington, and Axel Bruns. 2013. "Twitter as a Technology for Audience and Fandom. The \#Eurovision Phenomenon." Information, Communication \& Society 16(3):315-9.

Huckerby, Jayne. 2015. "When Women Become Terrorists." The New York Times, January 21, 2015. Retrieved February 20, 2015 (https://www.nytimes.com/2015/01/22/opinion/when-women-becometerrorists.html).

Ingram, Kiriloi M. 2016. "More Than 'Jihadi Brides' and 'Eye Candy': How Dabiq Appeals to Western Women.” ICCT Publications, August 12, 2016. Retrieved September 2, 2016 (https://icct.nl/publication/ more-than-jihadi-brides-and-eye-candy-how-dabiq-appeals-to-western-women/).

Issacharoff, Avi. 2016. "Women's Corps of ISIS: 'Hunting' Young Women, Imposing Penalties on Them and Forcing Them to Marry ISIS' Warriors." Walla News, May 28, 2016 (article in Hebrew). Retrieved September 2, 2016 (http://news.walla.co.il/item/2964898).

Ivanova, Miglena. 2016. "Prof. Tatiana Dronzina on 'Women in Islamic State'." Radio Bulgaria, February 8, 2016. Retrieved September 2, 2016 (http://bnr.bg/en/post/100656284/prof-tatiana-dronzina-on-womenin-islamic-state).

Jenkins, Brian M. 2015. "How the Current Conflicts Are Shaping the Future of Syria and Iraq." Perspective. Rand Corporation. Retrieved September 2, 2016 (http://www.rand.org/content/dam/rand/pubs/ perspectives/PE100/PE163/RAND_PE163.pdf).

Kaplan, Sarah. 2014. “Jihadi Brides': Young British Women are Among Islamic State's Newest Recruits." The Washington Post, September 10, 2014. Retrieved September 2, 2016 (https://www.washingtonpost. com/news/morning-mix/wp/2014/09/10/jihadi-brides-british-young-women-are-among-islamic-statesnewest-recruits/?noredirect $=$ on\&utm_term $=.3 \mathrm{c} 3325 \mathrm{c} 7 \mathrm{fd} 18$ ).

Katz, Jessica. 2015. "Where do the Women Fit in? A Theoretical Analysis of Western Women's Participation and Role in the Islamic State." Master's Thesis, Swedish Defense University, Sweden. Retrieved September 2, 2016 (http://frivarld.se/wp-content/uploads/2015/08/Masters-thesis-JessicaKatz.pdf).

Khaleeli, Homa. "The British Women Married to Jihad." The Guardian, September 6, 2014. Retrieved September 2, 2016 (https://www.theguardian.com/world/2014/sep/06/british-women-married-to-jihad-isis-syria).

Koerner, Brendan I. 2016. "Why ISIS is Winning the Social Media War." Wired, April 2016. Retrieved September 2, 2016 (https://www.wired.com/2016/03/isis-winning-social-media-war-heres-beat/). 
Manrique, Pedro, Zhenfeng Cao, Andrew Gabriel, John Horgan, Paul Gill, Hong Qi, Elvira M. Restrepo, Daniela Johnson, Stefan Wuchty, Chaoming Song, and Neil Johnson. 2016. "Women's Connectivity in Extreme Networks." Science Advances 2:e1501742.

McVeigh, Karen. 2014. "Female British Muslims as Vulnerable to Radicalization as Men, Study Shows." Guardian, October 15, 2014. Retrieved September 2, 2016 (https://www.theguardian.com/world/2014/ oct/15/female-british-muslims-vulnerable-radicalisation-men).

Miranda, Charles. 2015. “Terror Recruits: The Muslim Women Recruiting Friends and Social Media Followers to Create a Caliphate and Wage War." News Corp Australia Network, January 24, 2015. Retrieved April 2, 2016 (http://www.news.com.au/world/europe/terror-recruits-the-muslimwomen-recruiting-friends-and-social-media-followers-to-create-a-caliphate-and-wage-war/news-story/ 0681d5b65438531c2f1905f1030b42df).

Moore, A. M. T., G. C. Hillman, and A. J. Legge. 2000. Village on the Euphrates: From Foraging to Farming at Abu Hureyra. Oxford: Oxford University Press.

Myers, Russell. 2016. "Distraught Grandad of ISIS 'Jihadi Junior' Says Innocent Youngster Being Used as Propaganda by Terror Group.” Mirror, January 4, 2016. Retrieved April 2, 2016 (http://www.mirror.co. uk/news/uk-news/distraught-grandad-isis-jihadi-junior-7118187).

Nacos, Brigitte L. 2015. "Young Western Women, Fandom, and ISIS.” E-International Relations, May 5, 2015. Retrieved April 2, 2016 (http://www.e-ir.info/2015/05/05/young-western-women-fandom-and-isis/).

Neumann, Peter R. and M. Brooke Rogers. 2007. "Recruitment and Mobilization for the Islamist Militant Movement in Europe." A Study Carried out by King's College London for the European Commission (Directorate General Justice, Freedom and Security). London: King's College London, University of London.

Orlikowski, Wanda J. and Jack J. Baroudi. 1991. "Studying Information Technology in Organizations: Research Approaches and Assumptions." Information Systems Research 2:1-28.

Perešin, Anita. 2015. "Fatal Attraction: Western Muslimas and ISIS." Terrorism Research Initiative 9(3). Retrieved April 2, 2016 (http://terrorismanalysts.com/pt/index.php/pot/article/view/427/html).

Petrou, Michael. 2015. "What is Driving Teen Girls to Jihad?” Maclean's, March 7, 2015. Retrieved April 2, 2016 (http://www.macleans.ca/society/teen-girl-jihadists/).

Raghavan, S. V. and Viswanathan Balasubramaniyan. 2014. "Evolving Role of Women in Terror Groups: Progression or Regression?" Journal of International Women's Studies 15(2):197-211.

Reilly, Jill. 2014. "Twin Manchester Schoolgirls Who Ran Away to Syria 'Have Married ISIS Fighters and Mainly Stay Indoors and Read the Qur'an Unless their Jihadi Husbands Take Them Out'." Mail Online, July 24, 2014. Retrieved April 2, 2016 (http://www.dailymail.co.uk/news/article-2703792/TwinManchester-schoolgirls-ran-away-Syria-married-ISIS-fighters-mainly-stay-indoors-read-Quran-unlessjihadi-husbands-out.html).

Rotella, Sebastian. 2016. “ISIS via WhatsApp: 'Blow Yourself Up, O Lion'.” ProPublica, July 11, 2016. Retrieved April 19, 2018 (https://www.propublica.org/article/isis-via-whatsapp-blow-yourself-up-o-lion).

Saltman, Erin M. and Melanie Smith. 2015. “Till Martyrdom Do Us Part'. Gender and the ISIS Phenomenon.” ICSR: Institute for Strategic Dialogue. Retrieved April 2, 2016 (http://www.isdglobal.org/ wp-content/uploads/2016/02/Till_Martyrdom_Do_Us_Part_Gender_and_the_ISIS_Phenomenon.pdf).

Schofler, Patti. 2006. Flight Without Wings: The Arabian Horse and the Show World. Guilford, CT: Lyons Press.

Shorer-Zeltser, Marina and Galit Ben-Israel. 2007. “'Greater is our Terror of the Unknown': The Diasporic Internet Networks and Their Inference with Global Security.” Pp. 253-62 in Proceedings of the 6th European Conference on Information Warfare and Security, edited by D. Remenyi. Curtis Farm, UK: Academic Conferences.

Speckhard, Anne. 2016. "Brides of ISIS: The Internet Seduction of Western Females into ISIS Homeland Security Today.” Retrieved April 2, 2016 (http://www.icsve.org/brief-reports/brides-of-isis-the-internetseduction-of-western-females-into-isis/).

Sutten, Marne L. 2009. "The Rising Importance of Women in Terrorism and the Need to Reform Counterterrorism Strategy." School of Advanced Military Studies, United States Army Command and General Staff College, Fort Leavenworth, KS. Retrieved April 19, 2018 (www.dtic.mil/cgi-bin/GetTRDoc? $\mathrm{AD}=\mathrm{ADA} 506225)$.

Tarras-Wahlberg, Louisa. 2016. "Promises of Paradise? A Study on Official ISIS-Propaganda Targeting Women." Swedish National Independent Thesis, Advanced Level, Swedish Defence University. Retrieved April 19, 2018 (http://fhs.diva-portal.org/smash/get/diva2:942997/FULLTEXT01.pdf). 
Taylor, Rosie and Jaya Narain. 2014. "The British Jihadi Bride Hell-Bent on Murder - and Whining About her Lost Cat: 'Terror Twin' Tweets Fears for Missing Kitten - Before Posting Pictures of her Holding an AK47.” Mail Online, September 9, 2014. Retrieved April 24, 2016 (http://www.dailymail.co.uk/news/ article-2749939/The-British-jihadi-bride-hell-bent-murder-whining-lost-cat-Terror-twin-tweets-fearsmissing-kitten-posting-pictures-holding-AK47.html).

Vinograd, Cassandrt. 2014. "Jihadi Brides Swap Lives in the West for Front Line with Syria Militants." NBC News, July 8, 2014. Retrieved April 24, 2016 (https://www.nbcnews.com/storyline/iraq-turmoil/jihadibrides-swap-lives-west-front-line-syria-militants-n150491).

Winter, Charlie. 2015. Women of the Islamic State: A Manifesto on Women by the Al-Khanssaa Brigade. London: Quilliam Foundation.

Zakaria, Rafia. 2015. "Women and Islamic Militancy.” Dissent, Winter 2015. Retrieved April 25, 2016 (https://www.dissentmagazine.org/article/why-women-choose-isis-islamic-militancy).

Zingg, Geneviève. 2015. "Female Radicalization, the Islamic State, and International Security: An Opportunity." Pp. 14-16 in Canada In the World: Youth Dialogue on Women, Peace, And Security, edited by Kabir Bhatia and Saman Rejali. Toronto: The Atlantic Council of Canada. Retrieved April 25, 2016 (http://natoassociation.ca/wp-content/uploads/2015/05/Canada-in-the-World-Youth-Dialogueon-Women-Peace-and-Security.pdf).

\section{Abstracto}

Este artículo es parte de un esfuerzo por comprender el entusiasmo, la atracción y la admiración de la organización ISIS entre las jóvenes musulmanas de Europa occidental. El artículo se centra específicamente en los contenidos de Microblogging (Tumblr y Twitter) de jóvenes musulmanas de Europa occidental. El estudio ofrece una revisión de adoradores de Tumblr y tambien de ISIS en Occidente a través del prisma de la interpretación cultural. Las jóvenes, ya sean ellas mismas manipuladas o manipulando a otras, se vuelven parte de un sistema viral mundial producido al unísono perfecto y generan propaganda que atrae cada vez a más jóvenes musulmanas occidentales para convertirse en reclutas virales del ISIS. Después de mantener por un tiempo las cuentas Tumblr y Twitter, algunos de ellos incluso se someten al "Giant Leap" y emigran al "estado islámico" en Siria, continuando allí para reforzar sus esfuerzos de blogging y twittering, informando sobre sus vidas diarias e intentando tentar o atrapar a más jovenes para que se unan al nuevo "estado islámico".

Palabras clave: ISIS; “estado islámico"; fangirls; gatitos; contenido de redes sociales; microblogging; Twitter y Tumblr.

\section{Abstrait}

Cet article fait partie d'un effort pour comprendre l'enthousiasme, l'attraction et l'admiration de l'organisation ISIS parmi les jeunes femmes musulmanes en Europe occidentale. L'article se concentre spécifiquement sur le contenu Microblogging (Tumblr et Twitter) de jeunes filles musulmanes de l'Europe occidentale. L'étude propose un examen de Tumblr fangirls adorant ISIS en Occident à travers le prisme de l'interprétation culturelle. Les jeunes filles, manipulées ou manipulant des autres elles-mêmes, font partie d'un système viral mondial produit à l'unisson parfait et générant une propagande incitant de plus en plus de jeunes filles musulmanes en Occident à devenir des recrues virales de l'Etat islamique. Après avoir maintenu pendant un certain temps les comptes Tumblr et Twitter, certains d'entre elles font même le «saut géant» et migrent vers «l'Etat islamique» en Syrie, continuant à renforcer leurs blogs et reportages sur leur vie quotidienne et essayant de tenter ou de piéger plus de jeunes filles à rejoindre le nouvel «Etat islamique». 
Mots-clés: ISIS; "État islamique"; fangirls; petits chats; contenu de médias sociaux; Microblogging; Twitter et Tumblr.

摘要 :

这篇文章的部分成就是理解西欧年轻穆斯林女性对伊斯兰组织的狂热、被吸引和 钦佩。这篇文章特别关注西欧年轻穆斯林女孩的微博 (微博客和推特) 内容。这 项研究通过文化解读简述了崇拜伊斯兰国的微博客上的西方女粉丝。无论是被操 纵还是操纵他人, 这些年轻女孩都成为完美统一的世界性病毒系统中的一部分， 并引发越来越多的年轻的西方穆斯林女孩成为病毒式伊斯兰国新兵的招募者。微 博客和推特帐户维护一段时间后，他们中的一些甚至经历了“巨人飞跃”并迁移到叙 利亚的“伊斯兰国家”，继续在那里努力更新他们的博客和推特来报道自己的日常生 活 , 并试图诱惑或吸引更多的年轻女孩加入新的“伊斯兰国家”。

关键字：伊斯兰国、“伊斯兰国家”、女粉丝、小猫、社交媒体内容、微博、推特、微博客

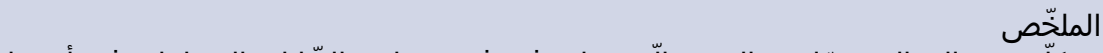

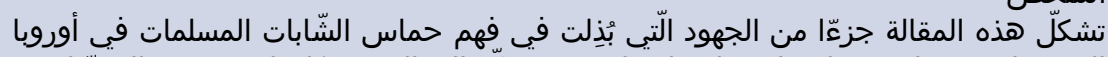

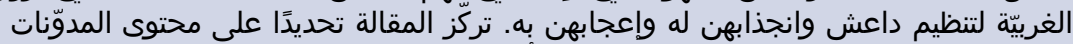

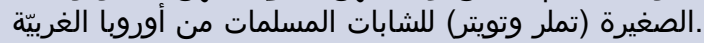

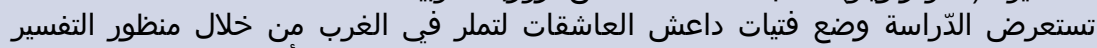

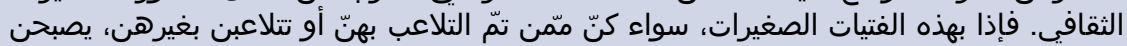

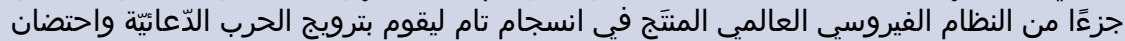

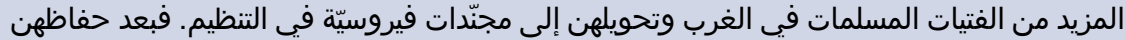

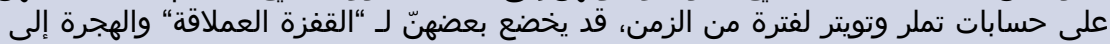

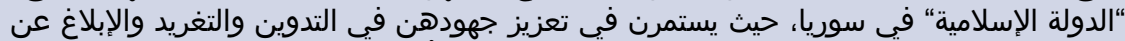

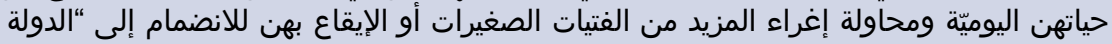

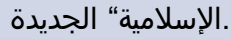

"الدولة الإسلاميةّة" ، المعجبات المهووسات، القطط، محتوى شبكات التّواصل الاجتماعي، المدوّنات الصغيرة، تويتر،

Galit M. Ben-Israel (Fixler) is the head of the project of Identity, Terror and CyberSpace, in the Institute of Identity Research (IDmap). Dr Galit Ben-Israel is also a terrorism expert and senior lecturer of political science at the Public Administration and Policy, The Faculty of Society and Culture, Beit-Berl Academic College. She teaches courses of: World Politics and Globalization; European and Palestinian Terror; A Cross-Cultural Comparison Terror on the Digital Era; Muslim Terror in the Digital-Global Era; Modernism and Postmodernism in Communications and the Digital Culture. Her research field covers themes of: hostagebarricade terrorism; indicators and databases for risk prevention; suicide terrorism; diaspora and Internet networks; social media and ISIS female recruits and disaster management via social media (Web 2.0).

Cite this article: Ben-Israel, GM. 2018. Telling a Story Via Tumblr Analytics: Europe's Young Muslim Female Attraction to ISIS. International Annals of Criminology 56: 55-78, doi: 10.1017/cri.2018.6 